Volkan Ertit*

\title{
God Is Dying in Turkey as Well: Application of Secularization Theory to a Non-Christian Society
}

https://doi.org/10.1515/opth-2018-0014

Received December 17, 2017; accepted March 12, 2018

\begin{abstract}
It has been stated in academic studies and popular media that Islam began its rise in dominance in Turkey with the accession of the Justice and Development Party (AKP) to power in 2002 under the leadership of Recep Tayyip Erdoğan. However, contrary to claims of societal Islamization, in light of quantitative and qualitative studies this study argues that despite the AKP and its leader Erdoğan being in power, the following evidence has been observed in Turkey: praying rates have decreased, extramarital sexual relationship has become prevalent, the number of mosques per person has decreased, the belief in virginity is a point of honour for fewer people, people's clothes have become more flatteringly formfitting and more attractive, including women's head-scarves; secular experts rather than religious officials are being sought for help concerning problems in daily life, homosexuality has become more socially acceptable visible, traditional family structures has been shattered. Therefore, it is claimed that AKP (or Erdoğan) has failed in efforts to Islamize Turkey over the past 15 years (2002-2017) despite having all the governmental means and opportunities to do so. This study argues that the classical theory of secularization, which claims that modernization leads to secularization, can still explain not only the social transformation seen in historically Christian and Western European countries and their offshoots, but also the social transformation of Turkey, a Muslim-majority country that has been governed for the past 15 years by a political party with clear Islamic sensitivities.
\end{abstract}

Keywords: Secularization, Secularization of Turkey, Secularization Theory, Modernization, Secularization in Islam

\section{Introduction}

In Turkey, the main axis of opposition against the Justice and Development Party (Adalet ve Kalknma Partisi or AKP) has conjured up concepts such as "Islamization", "neighbourhood pressure", or "Iranization" especially since 2002. ${ }^{1}$ A number of academics, journalists and opinion leaders claimed that Turkish society has adopted a more religious and conservative structure, particularly after the AKP's accession to power in 2002. ${ }^{2}$ For instance, in The Republic Protests ${ }^{3}$ of 2007 held in cities like Istanbul, Ankara, Izmir and Çanakkale and attended by millions of people, the criticism was that Turkish society had become greatly Islamized under the AKP government. It was emphasized in slogans shouted out in these rallies that they

1 Cinar, “Turkey’s Transformation”, 469; Çetin, “A Brief History of a Concept”, 85-86.

2 Anık, “Two axes revolving”, 25; Toprak et al., Being Different in Turkey.

3 The Republic Protests were a series of meetings held before the 2007 presidential election to prevent the election of any AKP member including Recep Tayyip Erdoğan as president, stressing that secularism was in danger.

*Corresponding author: Volkan Ertit, Aksaray University, Turkey; E-mail: volkanertit@gmail.com 
would not let Turkey become a new Iran, and the Turkish Armed Forces were openly called upon for a coup d'état to topple the ruling AKP. ${ }^{4}$

The campaign "Are You Aware of the Threat?" launched in 2006 by the Turkish daily Cumhuriyet [Republic] with a manifest preference for a laic state system, the 2007 lawsuit seeking AKP's closure since it was alleged to favour bringing in the Sharia Law to Turkey and the following penalty imposed by the Constitutional Court ${ }^{5}$ all supported the perception and claim of an "increasingly Islamized Turkey". Furthermore, certain legal steps and discourse in support of these steps such as clear criticisms made by the AKP's staff and primarily Recep Tayyip Erdoğan against the secular lifestyle, Erdoğan's “we will raise a pious generation" rhetoric, some AKP municipalities finding certain statues obscene and having them removed, opening of women-only beaches, increase in the number of religious high schools, mawlid (celebration of the Birth of the Prophet (PBUH)) programs broadcast on state TV channels, a ban on alcohol advertisements and Erdoğan's preference for a ban on the cohabitation of male and female students in the same house - have increased the perception of a relentless "Islamization" in Turkey. Therefore, the general perception about Turkey is that Islam, especially under the AKP government, has become a more dominant force in society.

However, this article argues that contrary to the perception of "Islamization" both at the national and international arena, AKP or Erdoğan, despite all efforts, has failed in the Islamization of Turkish society. Qualitative and quantitative studies indicate that the supernatural realm in general and Islam in particular have increasingly lost their power to influence society and have less impact on the daily lives of new generation. Just as it is claimed by the classical theory of secularization, modernization process has led to the secularization of Turkish society as well. Thus, after first clarifying a definition of secularization and examining the classical theory of secularization, we then explain how the process of modernization has expedited secularization of Turkish society. The new path taken by Turkish society that has become increasingly distant from Islam and, for that matter, anything supernatural will be described under seven subheadings. It should be stressed that this article is not based on an original research but is, instead, a collation of existing research into the social transformation which accompanied the modernization process in Turkey.

\section{Secularization theory}

Secularization, in this study, is defined as the relative decrease in the social prestige and social influence of a previously-dominant belief in a supernatural realm (i.e. religions, folk beliefs, religion-like structures, magic, etc.) within a defined period of time and in a particular place. ${ }^{6}$ Since religion is only one branch of supernatural, the concept supernatural realm is used as an all-embracing concept covering the fields of reasoning and thinking that are based on concepts and events which are supported by arguments of belief and intuition rather than experimentation and observation. As Charles Taylor stresses what is at stake is mainly the growing scientific consciousness, the growth of instrumental thinking, and the split between fact and value-influenced religion, culture and ethics. ${ }^{7}$

The classical secularization theory, on the other hand, claims that the process of secularization is intrinsically connected to the process of modernization, i.e. "industrialization of work; the shift from villages to towns and cities; the replacement of the small community by society; the rise of individualism; the rise of egalitarianism; and the rationalization both of thought and social organization". ${ }^{8}$ Parallel to this view, José Casanova also depicts the core thesis of the theory "as a process of functional differentiation and emancipation of the secular spheres - primarily the state, the economy, and science - from the religious [supernatural] sphere and the concomitant differentiation and specialization of religion [supernatural]

4 Güven, “The Language of Taksim Gezi Park Protests”, 22.

5 Öniş and Yllmaz "Between Europeanization and Euro-Asianism”, 16.

6 Ertit, "Secularization: The Decline in Supernatural Realm”, 5.

7 Taylor, "Two Theories of Modernity”, 25.

8 Bruce, “Modernisation, Religious Diversity”, 266. 
within its own newly-found religious [supernatural] sphere."9 In this context, it should be emphasized that since this article claims that social transformation taking place in Turkey may also be explained in the light of secularization theory, all transformations come with modernization, i.e. the decline of conservatism, social change, socio-economic developments, and changes in morality, are part and parcel of secularization discussions as well if they are related to the supernatural realm.

\section{Secularization of Turkey}

In terms of modernization process, Turkey has been undergoing processes similar to those of modern West European countries particularly after the second half of the $20^{\text {th }}$ century. Demographic transition, development in the education sector, structural change in the economic system, very striking transformation related to the institution of family, and advancements in modern medicine and technology have been realized since 1960s. ${ }^{10}$ The general welfare of Turkish society has improved with the impact of scientific developments, an industrial-based economy, and urbanization compared to previous periods.

In the discussions on secularization in Western Europe and North America, the rate of frequenting churches and change in the number who believe in God are considered as the most important criteria sometimes as the only criteria. ${ }^{11}$ It is not easy to oppose the notion that Church or faith stands at the centre of discussions on secularization in Christian societies where social visibility and influence of religion are reduced to the rate of frequenting churches and the number who believe in God. However, such a method, i.e. reducing the secularization debates to frequency of praying or the number who believe in God, may not provide an adequate picture of the social transformation seen in some non-Christian societies. As Charles Glock says:

The more integrated a religion is into the social structure, the more likely it is that the everyday actions of man are defined by religious imperatives. In Hinduism, [or Islam] for example, how a man deports himself from the time that he arises in the morning until he goes to bed at night is defined by customs which have the support of religious authority. (...) Expectations about what a person will do as a result of being religious include both avoiding certain kinds of conduct and actively engaging in others. ${ }^{12}$

The truth in Glock's statement can manifest itself more clearly when we compare present-day Islam and Christianity. For instance, Islam of the $21^{\text {st }}$ century demands being able to regulate many parts of daily life such as raising children, family relationships, clothing preferences, marriage, friendship, choice of school, selection of living environment, choice of occupation, sexuality, and so forth. Thus, changes in frequency of prayer and the number of believers may not suffice in understanding change in the social influence of Islam and other supernatural elements which seek to influence every area of life. Secularization studies that are to be conducted in Muslim-majority countries such as Turkey, Iran, Saudi Arabia, and so forth, must involve more than just the frequency of performing Friday prayer, fasting, hajj, and other Islamic practices. ${ }^{13}$ It may be argued that what someone has done throughout the whole week apart from merely performing the Friday prayer might provide a better insight into secularization debates. That is the reason why taking into account only the change in the frequency of praying or increase/decrease in the number of non-believers in Turkey may not be a sufficient basis for secularization debates. ${ }^{14}$ But (in addition to frequency of praying) which criteria should be taken into account in order to acquire better insights into the secularization debates regarding Muslim society? If it is claimed that a society with a Muslim majority like Turkey is becoming more closed and religious by the day (desecularized), the following social transformations may be expected:

9 Casanova, Public Religions in the Modern World, 19.

10 Koç et al., Demographic Transition of Turkey, 5, 15, 32, 42.

11 Davie, Europe: The Exceptional Case, 6-7.

12 Glock, "On the Study of Religious Commitment”, 106-107.

13 Ertit, "Secularization: The Decline in Supernatural Realm", 7.

14 Ertit, Secularization of Alevis in Turkey, 87. 
1. Increase in frequency of praying and number of believers.

2. Decline in the number of premarital or extramarital sexual relationships condemned fiercely by Islam and further Islamization of the Turkish family structure.

3. Decrease in the visibility and social recognition of homosexuality which is rejected in Islam.

4. Increased influence of folk beliefs that have supernatural elements.

5. Prevalence of a more modest dress code.

6. Increase in the social prestige of Islam.

7. Increasing reliance upon Islam as a reference in discussions on culture.

These seven criteria have been chosen because of their application and relevance to not only to the rise or fall in the number of pious individuals in Muslim societies but also to the examination of the factors of daily life that Islam attempts to regulate. As stated before, $21^{\text {st }}$ century Islam not only expects its followers to worship, but also tries to regulate many aspects of their daily lives with detailed customs and regulations. Thus, these seven criteria were chosen in order to better understand the influence of Islam and other supernatural elements on daily life. The abovementioned seven points are consistent with the claim that AKP has gradually 'religionized' society. However, studies on these subjects present a portrait of Turkey that has not been Islamized but has moved away from supernatural elements, and Islam in particular. The next section will analyze these seven points in light of recent studies on Turkish society and will discuss the reasons why AKP has failed in its efforts to Islamize Turkey for the past 15 years (2002-2017), despite having all the governmental means and opportunities at its disposal.

\subsection{Declining praying rates}

Peter Berger pointed to an increase in the number of mosques in his two visits to Turkey in the last 20 years as evidence of his claim that religion has become more dominant in Turkish society. ${ }^{15}$ However, contrary to Berger's observations, the number of mosques per person in Turkey has not increased, but decreased. While the number of mosques in Turkey was 57,060 in $1985,{ }^{16}$ it rose to 87,381 in early $2017^{17}$. In other words, there has been an increase of $53 \%$ in the number of mosques. However, during this period, the rate of population growth was $57 \%{ }^{18}$ When only the term of the AKP government is taken as a basis, the rate of increase in the number of mosques between $2002-2017$ is $15 \%{ }^{19}$ while population growth rate during the same period is $17 \%{ }^{20}$. It would seem thus that contrary to Berger's claim, the number of mosques per person in Turkey has even slightly fallen before and after the AKP government.

In line with the number of mosques per person, praying rates have also been declining in Turkey. According to the study "Conservatism, Family, Sexuality and Religion in Turkey" supported by the Open Society Foundation, the rate of those who fast throughout Ramadan dropped to 53.1\% in 2012 as opposed to $60.4 \%$ in 2006 , and the rate of those who said they never fast almost doubled at $12.3 \%$ from $6.4 \%$ in $2006 .{ }^{21}$ The rate of those said to be praying five times a day dropped to $28.2 \%$ in 2012 as opposed to $33.5 \%$ in $2006 .{ }^{22}$ Parallel to this, the "Conservatism Survey" conducted among 4860 participants in 36 provinces in Turkey by the Gezici Research Company to compare the years 2013 and 2015 for the United Nations also revealed a decline in the number of people who pray five times a day or said to intend to fast throughout Ramadan. According to the results of the survey, the rate of those who said to be praying five times a day dropped to

15 Berger, "Secularization Falsified".

16 Özcan, "A Quantitative Study of Mosques in Turkey”, 6.

17 Presidency of Religious Affairs, "Statistics on Mosques".

18 Turkish Statistical Institute, Statistical Indicators 1923-2009, 10; Turkish Statistical Institute, “Address Based Population Registration System".

19 T24, " 8 thousand 743 mosques were built in the last 11 years".

20 Turkish Statistical Institute, "Address Based Population Registration System”.

21 Yllmaz, Conservatism, Family, Sexuality and Religion in Turkey, 35.

22 Ibid. 
$26.2 \%$ in 2015 as opposed to $28.2 \%$ in 2013 . The rate of those who said they never pray went up from $22.7 \%$ in 2013 to $27.5 \%$ in 2015 . Those who said they would not fast at all throughout Ramadan went up from $24.9 \%$ in 2013 to $29.5 \%$ in $2015 .{ }^{23}$

During this period, for the first time in Turkey non-believers who had been growing in number have founded the Atheism Foundation under the motto: "No atheist or non-believer will be alone from now on". ${ }^{24}$ Furthermore, Sinan Yllmaz's PhD thesis, “Transformation of Turkish Family and Religion”, conducted among 2797 families came up with results in support of the abovementioned numbers. According to that study, $84 \%$ of the older generation think that the new generation is more indifferent to religious issues, while $87 \%$ think the young generation is "negatively" affected by Western values, and $80 \%$ consider the new style of free upbringing for young generation to pose a problem for traditions. ${ }^{25}$

After the numbers within the mosque community had declined and with, especially, the young generation failing to frequent mosques as often as they are expected by AKP, the Presidency of Religious Affairs launched a series of social and sports activities including karate, table tennis, badminton, tennis and volleyball training to "popularize interest in and attraction to the Quran education". ${ }^{26}$ This change reminds of the use of churches for different purposes other than praying in order to reach more people in Christian countries.

These data indicate a decline in the number of praying individuals compared to past years. However, it should be noted that declining rates in such dynamics as praying and having faith might be sharper if the comparison could have been made with the 1970 s when $80 \%$ of the population lived in rural areas and the average level of education was still very low.

\subsection{Increasing out-of-wedlock relationships, divorces and decreasing numbers of children... Is this Islamization?}

In November 2013, it was reported by various news agencies that Prime Minister Erdoğan would forbid female and male students from living together. In his political party group meeting, Erdoğan said that he thinks out-of-wedlock relationships are immoral, that it is not compatible with Turkish-Muslim culture for females and males to live together in the same house without being married, and that parents are unhappy about it and therefore, they will prevent it. ${ }^{27}$ Such a statement, as reported by news agencies, was an important "input" for those claiming that Turkey has become Islamized. However, a different reading can be made when we get to the bottom of the story.

It is obvious that one of the areas affected by the process of Islamization in a Muslim-majority society is the relationships between men and women. That is because Islamic rules not only prohibit sexual intercourse before wedding but also try to ensure that a man and a woman stay apart if they are not married. ${ }^{28}$ Flirting involving sexuality could still lead to death in Anatolian towns in $20^{\text {th }}$ century. ${ }^{29}$ It was believed that virginity ascribes honour not only upon a woman's but also upon her family. Waiting for evidence of a bloody sheet as proof of the bride's virginity on the wedding night was, until recently, a common marriage ritual among the family members of the bride and groom..$^{30}$ Thus, in the past, flirtatious behavior among young people was either avoided or conducted in secret within circles of friends with whom they could go out. ${ }^{31}$ Not only in villages or towns but also in most of the cities, young girls could not acquire a boyfriend nor were they allowed to go out with their fiancé alone.

23 CNN Turk, "Everything with Mirgün Cabas".

24 Website of The Association of Atheism: https://www.ateizmdernegi.org.tr/; Haber Turk, "Association of Atheism Approved by the State".

25 Yllmaz, Transition of Turkish Family and Religion, 213, 235, 243.

26 General Directorate of Sport, "Cooperation Protocol”.

27 AKP Group Meeting, "Speech of Erdoğan”.

28 Amman, "Implicit and Explicit Secularization", 50.

29 Bayatlı, Alevi Bride, 26; Yıldız, "The Custom Murders”, 221.

30 Kalav, "Purity and Gender”, 154-160.

31 Ertit, Secularization of Alevis in Turkey, 254. 
However, comprehensive research, covering 3,666 students studying in their first year at Hacettepe (in the city of Ankara) and Dicle Universities (in the city of Diyarbakır), and carried out in cooperation with the World Health Organization, provides important clues as to the social change that has taken place in terms of flirting. ${ }^{32}$ Until their first class at university, the rate of those who admitted to having had premarital relationship was $66 \%$ at Dicle University and $73.6 \%$ at Hacettepe University. Given the fact that the students were in their first class at university, it can be predicted that these rates would increase before marriage. In a similar research, when students of 9 Eylül University Medical Schools (in city of İzmir) were asked about their flirting experiences, the rate of the first-year female students who gave an affirmative answer was $65.2 \%$, which rose to $73.5 \%$ for the final-year female students. ${ }^{33}$ In addition, the ratio of those who say that "women have a right to premarital sexual intercourse" is 38.6\% among the students of Hacettepe and 25\% among those at Dicle University. ${ }^{34}$ Although these findings are crucial in terms of showing social change in a country where "out-of-marriage relationships used to end in death", ${ }^{35}$ it should be noted that these figures were from 15 years ago. That is, these figures are from a period when there were no social media such as Facebook-Twitter, Instagram, or smart phones. Furthermore, given the educational status of the parents of students involved in this study, the generation gap should become clearer. 78.7\% of Hacettepe students' mothers and $58 \%$ of their fathers (respectively $97.3 \%$ and $85.1 \%$ for Dicle University students) did not have university education. ${ }^{36}$

In line with this survey, another survey conducted in 2010 by Özer Sencar and S1tkı Yıldız revealed that $85 \%$ of students were open to flirting, about one third of them thought favourably of premarital cohabitation and $37.4 \%$ of female students did not agree with the idea of preserving their virginity. Researchers emphasized that there was increasing agreement with the opinion that "virginity is not indispensable and opposite sexes can live together without being married" compared to a similar survey conducted in $2006 .{ }^{37}$ Another survey conducted in 2012 showed that $59.4 \%$ of Turkish society is not uncomfortable with young people flirting. ${ }^{38}$

In line with these numbers, qualitative studies have also reached similar conclusions. Nalan Çelikoğlu's thesis, "The Transformation of Mahrem (Privacy) Among University Students in Turkey", revealed that in contrast to their mothers' experiences, limits on sexual intimacy have eased up among the new generation and different attitudes have emerged regarding sexual privacy between generations. ${ }^{39}$ Furthermore, in the thesis “Virtue and Virginity: What Is the Difference between Generations?” Özüm Dinçer concluded that girls have a freer lifestyle than their mothers and also do not value virginity as much as their mothers. ${ }^{40}$

In compliance with this new Turkish reality, studies indicate that despite the fact that, traditionally, the only legitimate type of sexual relationship for women in Islam is what they experience with their husbands after the wedding, sexuality experienced without marriage has increased in Turkey compared to the past. It's known that "as age at marriage rises, opportunities increase for premarital friendships, dating, and more serious partnerships between young males and females." ${ }^{41}$ In parallel to this, in Turkey, marriage age has risen to 27 for men and 24 for women, while the median age of the first premarital sexual intercourse has dropped to 19 for men and 20 for women ${ }^{42}$ which is not compatible with Islamic ethical codes. ${ }^{43}$

In a report prepared by the Ministry of Family and Social Policies, a surge in out-of-wedlock relationships, increase in the number of single-parent families, opposition to marriage and/or delaying marriage, and

32 Akın \& Özvarış, Factors affecting sexual and reproductive health.

33 Ozan et al., "Sexual attitudes and behaviors", 177.

34 Akın \& Özvarış, Factors affecting sexual and reproductive health, 73-74.

35 Erdentuğ, Cultural anthropological (ethnological) examinations, 23; Y1ldız, “The Custom Murders”, 221.

36 Akın \& Özvarış, Factors affecting sexual and reproductive health, 47.

37 Bayhan, "Youth and Postmodern", 153.

38 Yılmaz, Conservatism, Family, Sexuality and Religion in Turkey, 39.

39 Çelikoğlu, The transformation of mahrem (privacy), 186.

40 Dinçer, Virtue and Virginity, 139-140.

41 Brown et al., "Sexual relations", 6.

42 Association for Sexual Education, Treatment and Research, Youth and Sexuality; Association of Population Science, Sexual Health.

43 Unlawful sexual intercourse, called zinah, is strictly forbidden in Islam. For more information: Semerdjian, "Zinah". 
an increased tendency not to have children are accepted as risks faced by the family in modern Turkey. ${ }^{44}$ Studies suggesting that training should be provided for families to prevent out-of-wedlock relationships among their children were published, and Turkish media started to publish articles titled "Are out of wedlock relationships being encouraged?" 45

Hence, for the first time in the history of the Republic of Turkey, a prime minister stated that he is uncomfortable with out-of-wedlock relationships and that he wished to forbid them. This is because unmarried relationships have become so widespread for the first time in the history of Turkey, not only in big cities like Istanbul and Ankara but also even in small Anatolian towns known to be conservative - all taking place along with the "universitization" process. Higher education has also expanded rapidly for over a decade with the new established universities throughout the country. In 2003, Turkey's net enrolment rate in higher education was $14 \%$ and this figure drastically rose to $39-40 \%$ in $2015 .{ }^{46}$ Therefore, it is no coincidence that the rate of those who are not uncomfortable with "female-male couples living together in the same house without getting married" went up from 38\% in 2006 to $41.6 \%$ in $2012 .{ }^{47}$

As with increase in extramarital relationships, divorce rates in Turkey have also showed a rapid increase, particularly since the 1990s, in a way clearly not approved by religious people. While the number of divorces was 27,725 in 1993 , it rose to 126,164 in $2016 .{ }^{48}$ Within this same period, the population went up from 56 million to 89 million. That is to say, the divorce rate increased 4.5 times while population growth was only 1.4 times. Similarly, the meaning assigned to divorced women by Turkish society has changed as well. ${ }^{49}$ The rate of those who were uncomfortable with the presence of divorced women dropped to $11.2 \%$ in 2012 as opposed to $15.3 \%$ in $2006 .^{50}$

In addition, while the divorce rate has been increasing, the fertility rate has dropped drastically. The number of children per woman was 6 in the early 1960s in Turkey, but it fell to 2.1 in 2017 despite AKP's policy of tax reduction and financial support for families at least with 3 children. Pippa Norris and Ronald Inglehart's statements on the relationship between fertility rate and secularization based on a comparison of statistics concerning 76 countries provide in a way a succinct summary of what has been explained in this section:

The differential fertility rates of religious and secular societies is by no means a sheer coincidence; quite the contrary, it is directly linked with secularization. The shift from traditional religious values to secular-rational values brings a cultural shift from an emphasis on a traditional role for women (...) to a world in which women have an increasingly broad range of life choices, and most women have careers and interests outside the home. This cultural shift is linked with a dramatic decline in fertility rates (...). The evidence suggests that human development leads to cultural changes that drastically reduce (1) religiosity and (2) fertility rates. ${ }^{51}$

It should be noted that with the impact of modernization, the marriage age and divorce rates are rising in Turkey just as in West European countries, while alternative lifestyles including living alone or having extramarital relationships have emerged, and the fertility rate declines at the same time. Although the causes of these social changes are the subject of another study, social media platforms such as Facebook, Twitter and Instagram ${ }^{52}$, advance in women's education, increase in the number of financially independent women, individualization, prevalence of rapid and inexpensive hymen repair surgeries, not considering marriage as the continuation of property, TV series and TV programs displaying celebrities' extramarital relationships ${ }^{53}$, and universities whose number grew to 185 in 15 years are all factors that readily come to the fore.

\footnotetext{
44 Ministry of Family and Social Policies, Family Structure Research in Turkey, 34.

45 Gür \& Kurt, "Educational Needs of Families”, 34.

46 National Education Statistics 2015/'16: 1.

47 Yılmaz, Conservatism, Family, Sexuality and Religion in Turkey, 39.

48 Süleymanov, "Family and Marrige Relations”, 199; Turkish Statistical Institute, "Marriage and Divorce Statistics”.

49 Çayıroğlu, “The Psycho - Sociological Dynamics”, 16; Taylan, \& Danış, “Divorce in Turkey”, 47.

50 Yılmaz, Conservatism, Family, Sexuality and Religion in Turkey, 39.

51 Norris \& Inglehart, Sacred and Secular, 25-26.

52 Tüzer, “Internet, Cybersex and Infidelity”, 100.

53 Erkan, "Divorce in Turkey”, 15-16; Taylan, \& Danış, “Divorce in Turkey”, 48.
} 
It should be stated that there are not enough academic studies conducted in 1960s 1970s on those aforementioned subjects, when 80 percent of the population lived in rural areas. Keeping this in mind may provide much more grounded insights in respect to different life styles of individuals who grew up in rural areas in 1950s-70s and those who belong to generations ${ }^{54} \mathrm{Y}$ and Z (born in 1980-1995 and after 2000 respectively) living in urban areas, respectively.

\subsection{Turkey's new reality: homosexuals}

It would not be surprising to observe a decline in the visibility of homosexuals and restrictions in their rights in any society claimed to be increasingly dominated by Islam..$^{55}$ However, the experience of Turkish homosexuals, especially in the 2000s, is not consistent with the claim that the same society has been Islamized.

The first Gay Pride parade in Turkey was only attended by 10 people in 2003 but in 2013 and 2014 the parade involved more than 30,000 participants. ${ }^{56}$ Later Gay Pride parade were held not only in Istanbul but also in cities Ankara, Izmir, Mersin, Antalya, and Bursa, as well as in more conservatives/closed Anatolian cities of Malatya and Samsun. ${ }^{57}$ In addition, Lesbian, Gay, Bisexual, Transgender and Intersex (LGBTI) organizations were formed in 12 smaller cities, the formation of homosexual student associations in 19 universities where they had been previously banned, and the Kaos GL Association ${ }^{58}$ (founded in 1994) has become so organized that it could hold events against homophobia in 35 cities over 23 years. These are indicators of the expansion and diversification of the LGBTI movement. ${ }^{59}$ The recognition of homosexuality within the definition of 'normal' over time has also changed Turkish families' view of their homosexual children, and LISTAG (Families and Friends of Lesbians, Gays, Bisexuals, Transgender, Intersex Individuals $)^{60}$ has been established. In line with these developments, the rate of those who said they would not be uncomfortable with homosexual lifestyle rose to $29.1 \%$ in 2012 as opposed to $25.7 \%$ in $2006 .{ }^{61}$

Also, the images of the first gay marriage in Turkey that were reported in news websites in September 2014 epitomize how far Turkey has come with regard to homosexuality:

An unusual wedding in Istanbul: We did not hide in the face of the system

Ekin Keser who is 21 and Emrullah Tüzün who is 28 crowned their relationship with a wedding on September 2. What made their wedding distinct from others is that they are a gay couple. ${ }^{62}$

In 2017, Turkey's first "gay couple YouTube channel" also aired in such a way that it became the subject of prime time news. ${ }^{63}$ This transformation does not seem consistent with claims of the Islamization of Turkey.

\subsection{Folk beliefs disappearing with modernization}

The main point to be prioritized in discussions on secularization is how much the supernatural realm can affect daily life. Therefore, despite not being part of official or orthodox Islam, the social influence of supernatural elements such as contained in folk beliefs need to be analyzed as well for a comprehensive

54 Although there is no firm timeframe definition for these generations, the late 1970s and early 1980s are accepted as the beginning of the $\mathrm{Y}$ generation, while the beginning of the $\mathrm{Z}$ generation is set in the late 1990s and early 2000 s.

55 The Economist, "Islâm and Homosexuality, Straight but Narrow".

56 After 40,000 people came together and celebrated Gay Pride like a festival in 2014, the Governorship of Istanbul banned annual Gay Pride marches on security grounds in 2015 and for years after. For images of the İstanbul Gay Pride parade in 2014: https://en.wikipedia.org/wiki/Istanbul_Pride or https://www.youtube.com/watch?v=7kS45dz7BpY

57 Haber55, "Honor Walk in Samsun”; Kaos GL, "LGBTI Honor Walk in Malatya”.

58 Kaos Gay and Lesbian Cultural Research and Solidarity Association.

59 Yılmaz, "Fight for Equal Citizenship”, 174-175.

60 https://listag.org/english/

61 Yllmaz, Conservatism, Family, Sexuality and Religion in Turkey, 39.

62 Hürriyet, "An Extraordinary Wedding in Istanbul”.

63 Onedio, “Turkey's first youtube 'gay couple”. 
understanding of secularization, since they also have an impact on the individuals' daily lives. This is because the supernatural realm lies at the heart of secularization debates, and official religions are just part of the supernatural realm.

Before converting to Islam, Turks had their own folk beliefs, some of which still continue today. ${ }^{64}$ Besides, despite not being part of official Islam, folk beliefs legitimized through Islam have affected the daily life in society for years. For instance, refusing to pass scissors, knife or soap from hand to hand, consulting a man of religion rather than seeing a doctor when ill, shooting arrows to the sky or playing drum or tin cans in solar eclipses, throwing water after those who are leaving, not cutting a boys' hair until age six to avert the "evil eye", taking the ring off the left ear as ill-omen, considering jinni ${ }^{65}$ as the cause of psychological diseases, and saying prayers to the full moon while holding money are among such folk beliefs. In the interviews conducted in Turkey for a PhD study, jinn is mentioned as the cause of diseases:

An old interviewee from Tunceli region: If someone was discoloured, it was said that $\mathrm{s} / \mathrm{he}$ had been hit by demons. (...) Let's say a woman died of bleeding during childbirth, but in those days it was believed that a jinn called "heleke" actually came and took her lungs. ${ }^{66}$

It is neither surprising nor specific to Turkey that such beliefs affected people's daily lives in a time when modern medicine was not as advanced as today. Just 40 years ago, in 1970s, technology then was primitive, level of education was very low, and $80 \%$ of the Turkish society was living in rural areas. It is not unusual to hear of this kind of belief. However, it can be said, the growing number of hospitals and health professionals, the spread of scientific and technological knowledge, the growing reality of half of those turning 18 being able to go to university, the internet, the urban lifestyle, ${ }^{67}$ and so forth, have somehow blurred the presence of such beliefs at the social level, resulting in a decrease in their impact on the daily lives of $\mathrm{Y}$ and $\mathrm{Z}$ generations. Thus, this study argues that before modernization people first resorted to God or other supernatural entities to ease the troubles of everyday life. However, technological advances, urbanization and industrial capitalism that come with modernization have given rise to secular alternatives and they have helped individuals to be emancipated from the dependency on supernatural realm when facing difficulties. As a matter of course, this transformation puts distance between supernatural entities and individuals. ${ }^{68}$

\subsection{More European dress code}

Discussions over clothing, especially with regard to women, have constituted a significant part of the Turkish social agenda for many years. ${ }^{69}$ Conservatives blame those who wear clothes that reveal body shapes as sinners, and see women, and even men, adopting such style as the cause of social depravation and decay. ${ }^{70}$ Thus, in a society increasingly dominated by Islam, women (whether headscarfed or not) and men are supposed to adhere to a more loose-fitting dress code.

First of all, it should be noted that the percentage of women without headscarves rose from 27.3 percent in 1999 to 36.5 percent in $2006 .{ }^{71}$ However, along with the decline in the number of veiled women, there have also been changes in the way headscarves are worn which do not please those with traditional Islamic

64 Şener, Shamanism, 103-109.

65 "In Arabian and Muslim mythology, Jinn(i) is an intelligent spirit of lower rank than the angels, able to appear in human and animal forms and to possess humans." (https://en.oxforddictionaries.com/definition/jinn)

66 Ertit, Secularization of Alevis in Turkey, 240.

67 Albayrak \& Çapcioğlu, "Folk Beliefs and Practices”, 128.

68 Sarmış, "Secularization Strategy", 51.

69 Baban, "Secular spaces”, 644-646.

70 Iftar with Nihat Hatipoğlu, "Men should not wear Narrow Pants".

71 Çarkoğlu \& Toprak, Religion, Society and Politics in a Changing Turkey, 27. (Any longitudinal study on women without headscarves has not found from an earlier date.) 
sensitivities. ${ }^{72}$ Studies and a short walk on the streets in Turkey (including conservative cities) show that the new generation of Turkish women dress in a way that highlights their body lines more than previous generations. Today's veiled women have a more modern, colourful and tighter dress code than women wearing ferace - a long mantle with wide arms and body, and skirts to the floor - and long coats of the 1990s, and when the headscarf is excluded, their clothes and accessories are almost the same as or equivalent to those of a woman with no headscarf. ${ }^{73}$ According to Selda Karaaslan's study, "Reflections of Religion-based Social Changes on Women Clothes in Turkish Society After 1980", the most remarkable change in veiling clothing occurred after $2003^{74}$ :

Clothes have been exhibited in modern and luxury places and blonde models have been preferred (a European image) since 2003. Clothes are bright-coloured and eye-catching while models have tightly-fitting cuts and even cuts highlighting a certain part of the body every year. ${ }^{75}$

In parallel to this study, Banu Gökarıksel and Anna J. Secor also claim that "prominent veiling-fashion companies construct an ideal image of the Muslim woman as cosmopolitan, trendy, beautiful, and of a certain class status [which] (...) moves beyond the Islamic moral code."76

The transformation of veiling into a fashion object since the early 1990s has resulted in the emergence of fashion magazines with no Islamic concerns for veiled women. Studies focusing on these magazines reveal that such magazines stimulate luxury consumption rather than promoting religious claims. ${ }^{77}$ While describing the transformation observed particularly in relation to advertisements for veiling-fashion clothes, Fatma Barbarosoğlu first of all mentions the free-hand faceless illustrations seen in women's magazines from the 1980s. She describes the 1990s as a time when women wearing make-up, but with a neat appearance in their body language, were seen in catalogues. As for the early 2000s, she mentions that catalogues were filled with photographs underlining the message "I am here", for they highlight women wearing make-up as well as revealing body shapes, just as stressed by Karaaslan. ${ }^{78}$

Along with women, young men of the $21^{\text {st }}$ century also pay more attention to their "masculine" appearance compared to previous generations. The image of a man who has a "six-pack", Adonislike muscles, broad shoulders and is interested in cosmetics and being "classy", as idealized in men's magazines, ${ }^{79}$ can receive traditional and social media coverage while the body lines of TV series actors are presented as success stories in news websites..$^{80}$ Male singers who do not have a super-fit appearance are exposed to social criticism because of their droopy chest or belly ${ }^{81}$ Fitness centres have increased in number in small Anatolian towns, let alone in big cities, and thus a fierce competition environment has emerged. ${ }^{82}$ As Akif Öztürk says in his paper, "Male Embodiment: The Construction of Hegemonic Male Body":

(...) since the late 90 s, there seems to be a remarkable increase in coverage of the male body in tabloid magazines, advertisements or similar popular culture and media products. (...) There has been a shift from the traditional stereotype that men stare at women and those who are objectified are women to a different stereotype that men too are sexually objectified and offered to gazes. ${ }^{83}$

72 Gökarıksel \& Secor, “Ethical Practice of Veiling-Fashion in Turkey”, 859.

73 Eke, Perception of Body Presented in Media, 119-120; Köse, Laic but Sacred, 16.

74 AKP came to power in 2002.

75 Karaaslan, Social changes on woman clothes, 184.

76 Gökarıksel \& Secor, "Islam on the Catwalk”, 2583.

77 Meşe, “Consumption, Religion and Woman”, 108.

78 Barbarosoğlu, Show and Private, 126-129.

79 Erdoğan, “A Content Analysis of Ideal(ized) Masculin(ity)'s”, 160-161.

80 Sabah, "Kıvanç worked for a fit body for six months".

81 Hürriyet, "Breast Reduction Surgery".

82 Yıldız \& Tüfekçi, "Assessment of Expectations and Perceptions”. 2

83 Öztürk, "Male Embodiment”, 46. 
What teachers with 23, 21 and nine years of high school teaching experience say about their students with regard to flirting could provide a wider and better perspective on teens “...[i]ncreasingly having shorterterm relationships and more flirts, exposing their feminine body lines more, going to each other's homes and sending naked photos to each other, kissing even in education institutions, preferring skinny jeans and tights that reveal their body lines". ${ }^{84}$

\subsection{Islam's declining prestige}

In a society where Islam has become more influential and is gaining prestige by the day, one might expect a concurrent increase in its reflections in daily life. However, recent social changes in Turkey suggest the prospect of a different scenario.

For instance, while imams of Sunni denomination had the influence and prestige to affect every area of life when there was no structural and social differentiation and the majority of the population lived in rural areas, they have lost their social influence due to the rapid urbanization and developments in modern medicine. Imams who were consulted about issues of birth, education, wedding, marriage, moral issues, diseases, death, disagreements among villagers, and even for official or unofficial proceedings in the 1970s when over $75 \%$ of the population lived in rural areas now perform only official duties (in mosques) that are specifically defined for them in today's urban's setting. ${ }^{85}$ As urban hospitals, courthouses and schools have their own specialists, a number of fields previously controlled by imams are now dominated by secular specialists in the urban setting. Therefore, the position of imams has shifted from the respectable specialist in every field of life to that of the "government official leading prayers at mosques".

Along with Sunni imams, Alevi Dedes ${ }^{86}$ also seem to be affected by this process. Dede used to be regarded as Caliph Ali's representative on earth. Their orders were accepted above the law and their decisions were implemented without question by Alevis. Besides, they had the power to excommunicate individuals as is the case in the Catholic Church. However, they have also lost their influence and prestige in the urban setting. "Today, especially in urban environments, the mediating functions of the dede seem to be gone; they had been tied into the socio-economic fabric of traditional Alevism, which largely eroded due to urbanization and secularization". ${ }^{87}$ Probably, the most caricaturized example that shows how the institution of Dede has lost its power and prestige is the case of an Alevi dede who was brought to trial by one of his followers: "An Alevi in the city of Burdur sued the Alevi dede for libel for having declared the Alevi to be 'decayed' for committing adultery. The court ruled in favour of the follower". ${ }^{88}$ In addition, as Fuat Bozkurt has observed, new generations who are entitled to be dede do not seem so eager to replace older ones due to increased job opportunities that provide better living conditions. ${ }^{89}$

Two denominations of Islam, Alevism and Sunnism, were so influential in the past that they drastically affected people's daily lives, e.g. spouse selection. ${ }^{90}$ Until recently, marriage to someone from a different denomination led to severe consequences such as excommunication from both family and community. ${ }^{91}$ In parallel, as stated by Aykan Erdemir in a study on Alevi community, a great number of Sunnis viewed the Alevis as heretics and perverts. ${ }^{92}$ They were to believe that the Alevis practise orgies in congregational ceremonies and incest. Interactions between Sunnis and Alevis were so limited that Sunnis living in some settlements in Anatolia in the 1970s believed that Alevis were tailed and horned creatures. ${ }^{93}$

84 Ertit, The Age of Anxious Conservatives, 73-74.

85 Ozan, The image of religious officials, 76; Yavuz, "The Imams of the Village”, 175.

86 The dede, literally means Grandfather, is the practitioner of the Alevi faith. Basically, the dede is the holy man of Alevism, which is the only person capable of conducting religious ceremonies.

87 Dressler, "Religio-Secular Metamorphoses", 295.

88 Haber Turk, "The judiciary ignored the Alevi law".

89 Bozkurt, “State-Community Relations”, 86.

90 Yıkmış, Ulusoy Family, Descendants of Hacı Bektaș Veli”, 193-204.

91 Doğruel \& Leman, “'Conduct' and 'Counter-conduct”', 597; Zeidan, “The Alevi of Anatolia”, 76.

92 Erdemir, Incorporating Alevis, 31.

93 Ertit, Secularization of Alevis in Turkey, 247. 
Since people are not asked about their religious identity in civil marriage, it does not seem possible to provide data on interfaith marriages. However, qualitative studies on the subject reveal that interfaith marriages have significantly increased over the years. ${ }^{94}$ Family elders in particular say that marriage to someone from other faiths was not allowed in their time but the new generation does not have such concerns. ${ }^{95}$ Similarly, Nail Yllmaz's field study on urbanized Alevis revealed that more than half of Alevis sees no problem to get married to Sunnis. ${ }^{96}$

It seems that the process of modernization has made it difficult for denominations to continue to exist in isolation within their own settlements. The shift from an agricultural society to an industrial society, urbanization and globalisation has led to a mixing of various religious backgrounds in the city. When it comes to marriage, this process has caused both Alevism and Sunnism to adopt a more moderate tone, preventing religious identity from becoming the determining factor. ${ }^{97}$ The decline in the influence of religious identities on daily life compared to the past, i.e. what was impossible before for religious reasons is now being openly exhibited, can be read as a reflection of the secularization process but not Islamization.

Another area in which Islam's prestige has declined is baby names. As Tayfun Amman noted, the examination of "language" is particularly important in the analysis of social change..$^{98}$ Identifying which words and usages fall into disuse or start to be used in "language" as a significant determinant and conveyor of culture to the next generations provides useful information about the nature of this change. From this perspective, studies of baby names in Turkey yield results that are not consistent with the claim that Islam has dominated Turkish society more than ever before. According to a field study conducted in Konya, famous for its conservative culture, young people in the 18-35 age group have less religious attachment towards baby names and look for "striking, attractive, mysterious, aesthetic, natural-sounding, trendy, and fancy" names. ${ }^{99}$ Statistics published by General Directorate of Population and Citizenship Affairs also help generalize this specific study conducted in Konya. While the top five names preferred for girls in Turkey between 1930-1990 were Fatimah (Mohammad's daughter and Ali's wife), Aisha (Mohammad's wife), Aminah (Mohammad's mother), Khadija (Mohammad's first wife) and Zainab (Mohammad's daughter), four of these religious names (except Zainab) did not rank even among the top 20 in 2014, 2015 and 2016. ${ }^{100}$

In line with these changes, as a prestigious and prominent Turkish scientist Hakan Yllmaz depicts, the rates of those who are uncomfortable with women dressed in a way that is not compatible with Islam (from $52 \%$ in 2006 to $34.6 \%$ in 2012), of those who are uncomfortable with those who do not fast (from $33.3 \%$ in 2006 to $25.4 \%$ in 2012), of those who are uncomfortable with those who do not pray (from $26.4 \%$ in 2006 to $18.6 \%$ in 2012), and of those who are uncomfortable with those drinking alcohol (from $65 \%$ in 2006 to 52\% in 2012) have all declined. ${ }^{101}$ In addition, seeing a man wearing an earring - a fashion once criticized and which, for years, had led to violent events on the ground that it contradicted the image of a Turkish-Muslim man - has become more acceptable in society. The rate of those who were uncomfortable with men wearing earrings dropped to $41.9 \%$ in 2012 as opposed to $52.8 \%$ in 2006.

On the issue of abortion, the rate of those who approve of it (if a woman does not want to give birth for any reason) has risen to $56.3 \%,{ }^{102}$ which points to a general tendency in society to approve of abortion despite the anti-abortion policies pursued by the AKP.

94 Erdem, Secrets and Revelations, 169; Firat, “The Alevi Perception of Alevism”.

95 Ertit, Secularization of Alevis in Turkey, 263.

96 Yllmaz, Urbanized Alevis, 288.

97 Ertit, Secularization of Alevis, 260-267.

98 Amman, "Implicit and Explicit Secularization”, 55.

99 Çelik, Name Culture and Religion, 200-201.

100 General Directorate of Population and Citizenship Affairs, "Name Statistics".

101 Yllmaz, Conservatism, Family, Sexuality and Religion in Turkey, 39.

102 Ibid., 41. 


\subsection{The rise of secular discourse}

While explaining secularization in the USA Steve Bruce argues that the language preferred by Christian right organizations to influence public opinion is not religion-oriented, but has a secular tone.

They cannot say that Creation should be taught in schools because God requires it. They have to accept the primacy of secular science and argue that the Genesis account of the origins of species is as consistent with the scientific evidence as any other explanation. They cannot assert that their God dislikes divorce. They have to argue that divorce is socially dysfunctional. ${ }^{103}$

A shift similar to that in the USA is also reflected in the language adopted by conservatives in Turkey. The tone that stands out in matters such as abortion, adultery, alcohol and homosexuality does not reflect a religious but rather a secular bent in the discussions:

- Pork should not be eaten, because it is a filthy animal believed to thrive on its own feces;

- There should be no divorce because family is the foundation of society;

- We should pray, because it has sports and hygienic benefits;

- We should fast, because it is good for the health according to the specialists;

- There is no evolution but genesis, because transitional forms do not exist according to science;

- Head-scarf "problem" is a human rights issue.

For example, during the Population Conference 2012, Recep Tayyip Erdoğan, then-Prime Minister, made the following statement in a discussion on abortion: "I consider abortion to be murder. No one should have the right to allow this to happen. You either kill a baby in the mother's womb or kill it after birth. There is no difference". ${ }^{104}$ Also, then-President of the Religious Affairs, Prof. Dr. Mehmet Görmez, had this to say: "just as neither the mother nor the father has the right of possession of the baby, they do not have the power to give up on, or end, its life". ${ }^{105}$ Then-Deputy Prime Minister, Bülent Arınç, also chimed in: "So, abortion is about endangering the mother's health and almost making the baby's life miserable, killing it”. ${ }^{106}$ In addition, in 1994, the Presidency of the Religious Affairs was suggesting that family problems would be solved if the orders of Islam and Allah were followed. However, an academic study published in 2007 showed that this approach was abandoned, and instead of emphasizing the orders of Islam and Allah, love and mutual understanding are highlighted in sermons. ${ }^{107}$

To prohibit abortion, both politicians and opinion leaders emphasize the "individual's right to live" rather than quoting Quranic verses. In line with the example of the issue of abortion, those who support the prohibition of alcohol try to convince or influence public opinion by emphasizing alcohol-related health hazards rather than using the argument that "alcohol is not allowed in Islam; thus, it should be prohibited". If it is homosexuality that is in question, it is argued that that homosexuality must be prohibited and its practitioners are to be rehabilitated, because the way things stand, we will have a world without children in the future. However, they could also have said: "homosexuality must be prohibited because Islam says so" - but this stance is not applied.

Ural Manço also observed a similar transformation in one of the most radical religious group, the Naqshbandi sect. By analyzing 140 lectures of the M. E. Cosan, (a renown academic and leader of the sect) delivered between 1984 and 2001, Manço observed that religious discourses of the sheikh had become more rational and secular with the disciples' process of urbanization and social mobilization. ${ }^{108}$

103 Bruce, Secularization, 171.

104 NTV, "Erdoğan: Abortion is murder”.

105 Sabah, "Declaration on Abortion by Religious Presidency".

106 Milliyet, "Boyner was scolded by Arınç".

107 Özbolat, “Change in Discourse in the Sermons”, 676.

108 Manço, "Secularization in the Speech of the contemporary Naqshbandi brotherhood”, 479. 


\section{Counter arguments}

Those who maintain that Turkish society is becoming desecularized by the day are referring to either the report titled Being Different in Turkey - Research Report on Neighbourhood Pressure by Binnaz Toprak et $a l$. or the attempts by Recep Tayyip Erdoğan who has been in power since 2002 to create a pious society. However, if the subject in question is secularization, such claims are methodologically problematic in some respects.

The report of Toprak et al. reveals the problems being experienced by secular segments of society occur in the Anatolian cities known to be particularly conservative. However, the researchers only attempted to describe the current situation without needing to make comparisons to the past. Published in 2009, the report did not provide any information about the years 1999, 1989 or earlier, and only dealt with the year 2009. However, although studies that include single timeframes are helpful in terms of descriptions, they are neither usable nor useful for understanding the process of secularization because secularization is not the description of a situation but the definition of a process. ${ }^{109}$ This detail is crucial because if religionbased social pressure in 2009 was less than in previous years, then the report itself could be construed as supporting the process of secularization. To give an example of this claim, an interview given in the report should be mentioned. When we examine the statements of a teacher who explains how the society she lives in is being pressurised, it is also found that she leads a more secular lifestyle compared to the past:

“A teacher who is a member of Eğitim-Sen [a teachers' union] informed us that there were no open restaurants during Ramadan up until three to five years ago and the open restaurants were being stoned and shut down at that time. She added: 'Nowadays restaurants are open, but no one would eat out on the street, otherwise people would give them dirty looks. ${ }^{110}$

This particularly important detail, as expressed by the teacher, seems to have escaped Toprak's and other researchers' attention. The teacher claims that there were no open restaurants during Ramadan in the city of Kayseri in the past because any open restaurants were often stoned. However, she also adds that restaurants are now open and not stoned anymore. The fact that restaurants, which used to be closed in the past due to religious pressure, are now open is also indicative of secularization. It should be noted that keeping restaurants open during Ramadan has also been observed in other "conservative" cities, i.e.: Erzurum, Aksaray, Konya and Sivas where Recep Tayyip Erdoğan received more than $60 \%$ of the votes. ${ }^{111}$

In addition, some researchers in Turkey counter the claims made in this paper by citing the following: "[t]he rise in the number of personnel in the Presidency of Religious Affairs, rise in the number of Religious High Schools, rise in the number of Faculties of Theology, enhanced social and political influence of the Presidency of Religious Affairs, the spread of Values Education as a project throughout Turkey, increased religiosity in Nationalist and Conservative party rhetoric, rise in the number of elective religion courses in primary schools, rise in the number of foundations and associations established with the sole purpose of teaching the Quran, and an increase in Islamic dormitory activities". ${ }^{112}$ To these may be added the following cases as examples (although the researchers did not mention them): the "[b]an on alcohol advertisements, Erdoğan's attempt to prohibit adultery by law when he first came to power, removal of statues that were considered obscene by municipalities, municipal attempts to ban businesses that sell alcoholic beverages, opening of women-only beaches, allowing veiled women to work in the public sector, empowerment of Islamic capital, restrictions on studio apartments with the claim that they are not compatible with public morality." 113 These examples might be multiplied. However,

109 Bruce, "Secularisation”, 546-547.

110 Toprak et al., Being Different in Turkey, 37.

111 Ertit, The Age of Anxious Conservatives, 176.

112 Karaarslan, “Book Review of Anxious Conservatives”, 154; Sağır, "Prolegomena to the Age of Anxious Conservatives”, 796. 113 Ertit, The Age of Anxious Conservatives, 142-143. 
these factual cases demonstrate only the tip of the iceberg, and additionally serve to hide the truth that Turkey is a rapidly secularizing society. The main duty of sociology is to make visible the parts of social reality that are hard to see, and try to understand and make sense of it. ${ }^{114}$

Therefore, it should be emphasized that these examples indicate that the Islamic sensitivities of those in power (Erdoğan and its political party) - and not that of society - have increased and that not all such Islamic sensitivities of government officials are necessarily reflected in society. As in the case of Turkey, society can become distant from considerations of a supernatural realm even as the Islamic sensitivities of those in power increase. A ban on the sale of alcohol after 10 p.m., or making its sale difficult does not mean that the new generation is going to consume less alcohol for religious reasons. On the contrary, there is a current discussion in Turkey on the rise in homebrewed beer. ${ }^{115}$ In addition, an increase in the number of elective religion courses does not guarantee that students are, or will be, interested in such courses. On the contrary, as recent research has shown, students are not as eager to enrol in elective religion courses as government officials wish. ${ }^{116}$

It would not be a far-fetched inference to say that such a relationship between the State and society could also be observed in Iran as much as in Turkey. Although the Islamic Republic of Iran has been governed by shari'a law since 1979, a considerable segment of Iranian society lives a secular lifestyle. The research carried out by Abdolmohammad Kazemipur and Ali Rezaei shows that Iranian society has not become as religious as its State. ${ }^{117}$ Iranian women cannot remove headscarves in public places and Iranians cannot drink alcohol in public because of state law. However, in realms where the state does not interfere especially inside the homes - many Iranians do not hesitate to follow a secular lifestyle. The Iranian house parties (since they do not have the opportunity to have parties anywhere else) are places where women wear clothes which reveal cleavage, where many kinds of alcohol are consumed, and where women and men are free from the religious laws imposed upon them by the state. ${ }^{118}$ The present religious regime seems to have a society which adheres to an increasingly secular lifestyle day by day. ${ }^{119}$ Contrary to popular assumption, the laws (particularly related to the supernatural realm) enacted by the state do not automatically render societies religious, as can be seen in the cases of Turkey and Iran.

\section{Conclusion}

It is no secret that Recep Tayyip Erdoğan and his party (AKP) that has been in power since 2002 want to build a more pious society using both law and Islamic discourse. Erdoğan's efforts have led to the emergence of a perception both in Turkey and abroad that the country is being Islamized. However, in light of the abovementioned quantitative and qualitative studies, it can be argued that although 'top-down' religiosity has been imposed by the AKP government, Turkish society and its new generations in particular do not seem to have participated in the transformation that Erdoğan has wished to realize. While the AKP governments have made the state more sensitive to religious issues, it is also seen that Islam's prestige and influence have declined in the social arena. Erdoğan's efforts to Islamize Turkey seem to be blighted due to the dynamics of modernization such as urbanization, capitalism, and scientific developments.

As claimed by the classical theory of secularization, along with modernization, the new generation of Turks have a lifestyle that is more removed from arguments from supernatural dynamics (with reference to Islam in particular) than has been the worldview of their parents. This social transformation has meant that the number of those who pray and fast has declined, the number of individuals who believed that Quran is

114 Amman, "Implicit and Explicit Secularization”, 42.

115 Hurriyet Daily News, "Rise in Homebrewed Beer".

116 Gündoğdu, "Elective Religion Courses”, 578.

117 Kazemipur \& Rezaei, “Religious Life under Theocracy”, 357.

118 Many pictures of the new generation of Iranians who are not dressed in the way required by the state can be seen in this link: http://maxfux.livejournal.com/265190.html. Some of the house parties can also be watched in this link https://www.youtube.com/watch?v=30BU9VMrIgI

119 Lotfi, Kabiri \& Ghasemlou, “Conflict and Change across Generations”, 110. 
God's words has decreased, virginity represents honour for fewer people, extramarital sexual relationships have increased, the age of first sexual intercourse has dropped to high school age, divorce is no longer a taboo, traditional family structure has been shattered, Alevism or Sunnism is far from influencing daily life, clothing has gotten tighter, secular specialists rather than imams are asked for help concerning problems of daily life. What these portray is a secularized Turkey, much more than an Islamized one.

The secularization of a modernizing Turkey indicates that the classical theory of secularization may provide valuable insights into the social transition of other Muslim-majority countries as well. It should be said that, specifically for Turkey, this social change due to modernization does not seem to be affected by the laws enacted by a conservative government and the rhetoric of those in power. It seems that the new generations who socialize on Facebook, Twitter and Instagram, instead of the traditional family environment, portray a very different Turkish society from the one envisioned by the state. Therefore, it would not be far-fetched to see the social transformation which Turkey has been, and is, undergoing by means of "secularization" explained in light of the classical theory of secularization - that is, until new studies possibly provide findings to the contrary.

\section{References}

Akın, Ayşe \& Özvarış, Şevkat Bahar. Adölesanların cinsel ve üreme sağlığını etkileyen faktörler projesi. [Factors affecting sexual and reproductive health of adolescents]. Ankara: Hacettepe University Women's Studies Research and Application Center, 2003.

AKP Group Meeting. “Speech of Erdoğan.” 2013 November 5. Retrieved from http://www.milliyet.com.tr/Milliyet-Tv/video-izle/ Tartisilan-sozlerine-aciklama-U5uTiuvYsRXj.html [Last visited 11/04/2018]

Albayrak, Ali \& Çapcıoğlu, İhsan. “Ehl-i Sünnet Geleneğine Bağlı Bir Orta Anadolu Köyünde Halk İnançları ve Uygulamaları [Folk Beliefs and Practices in a Central Anatolian Village Depended on the Tradition of the Ahl-i Sunnah]." Religious Studies, 8:24 (2006), 107-132.

Amman, M.Tayfun. “Ailenin Açık ve Örtük Sekülerleşmesinin Sosyolojik Analizi [Sociological Analysis of Explicit and Implicit Secularization of Family].” In Aile ve Eğitim [Family and Education], edited by M. Faruk Bayraktar, 41-70. İstanbul: Ensar Neşr, 2010.

Anık, Mehmet. "Two axes revolving around the discussions of secularism in Turkey: Şerif Mardin and İsmail Kara." Human \& Society, 2:4 (2012), 9-34. DOI: http://dx.doi.org/10.12658/human.society.2.4.M0056

Association for Sexual Education Treatment and Research. Gençlik ve Cinsellik [Youth and Sexuality]. 2007, May 8. In www. cetad.org.tr. Retrieved from http://www.cetad.org.tr/yayinlar/list/43/genclik-ve-cinsellik [Last visited 11/04/2018]

Association of Population Science. Gençlerde Cinsel Sağlık ve Üreme Sağlığı Araştırması, Türkiye 2007 [Sexual Health and Reproductive Health Research in Youth, Turkey 2007]. 2007, December. In www.nd.org.tr. Retrieved from http://www. nd.org.tr/images/other/245.pdf [Last visited 11/04/2018]

Barbarasoğlu, Fatma Karabıyık. Şov ve Mahrem [Show and Privacy]. İstanbul: Timaş Yayınları, 2006.

Baban, Feyzi. "Secular spaces and religious representations: reading the headscarf debate in Turkey as citizenship politics." Citizenship Studies, 18:6-7 (2014), 644-660. DOI: http://dx.doi.org/10.1080/13621025.2013.865900

Bayatlı, Osman. Bergama'da Alevi Gelini ve Inançları [Alevi Bride and Faiths in Bergama]. İzmir: Teknik Kitan ve Mecmua, 1957.

Bayhan, Vehbi. “Gençlik ve postmodern kimlik örüntüleri üniversite gençliğinin sosyolojik profili (İnönü üniversitesi uygulaması) [Youth and Postmodern Identity Pattern Sociological Profile of University Youth (Inonu Unıversity Case)]." Gençlik Araştırmaları Dergisi [Journal of Youth Studies], 1:1 (2013), 134-157.

Berger, Peter L. “Secularization Falsified.” 2008, February. In www.firstthings.com Retrieved from https://www.firstthings. com/article/2008/02/secularization-falsified [Last visited 11/04/2018]

Bozkurt, Fuat. "State-Community Relations in the Restructuring of Alevism.” In Alevi Identity, edited by Tord Olson, Elisabeth Özdalga \& Catharina Raudvere, 85-96. Istanbul: Swedish Research Institute, 2005.

Brown, Ann Denise, Jejeebhoy, Shireen, Shah, Iqbal Hussain, \& Yount, Kathryn M. "Sexual relations among young people in developing countries; evidence from WHO case studies report.” Geneva: World Health Organization, 2001 January. Retrieved from http://apps.who.int/iris/bitstream/10665/66836/1/WHO_RHR_01.8.pdf [Last visited 11/04/2018]

Bruce, Steve. “Modernisation, Religious Diversity and Rational Choice in Eastern Europe.” Religion, State and Society, 27: 3-4 (1999), 265-275. DOI: http://dx.doi.org/10.1080/096374999106476

Bruce, Steve. "Secularisation, Church and Popular Religion”. The Journal of Ecclesiastical History, 62:3 (2011), 543-561. https://doi.org/10.1017/S0022046909992715

Bruce, Steve. Secularization. Oxford: Oxford University Press, 2011.

Casanova, José. Public Religions in the Modern World. Chicago, IL: The University of Chicago Press, 1994. 
Cinar, Menderes. “Turkey’s Transformation Under the AKP Rule.” The Muslim World, 96:3 (2006), 469-486. doi:10.1111/ j.1478-1913.2006.00138.x

CNN Turk. “Mirgün Cabas'la Her Şey [Everything with Mirgün Cabas].” 2017, July 16. In www.cnnturk.com. Retrieved from http://www.cnnturk.com/tv-cnn-turk/programlar/her-sey/her-sey-16-temmuz-2015 [Last visited 11/04/2018]

Çarkoğlu, Ali \& Toprak, Binnaz. Religion, Society and Politics in a Changing Turkey. Translated by Çiğdem Aksoy Fromm. İstanbul: TESEV, 2007.

Çayıroğlu, Yüksel. “Modern Zamanlarda Ailevi Çözülmenin Psiko-Sosyal Dinamikleri [The Psycho - Sociological Dynamics of Dissolution of Family in the Modern Age]." Mehir Aile, 3 (2016), 11-40.

Çelik, Celaleddin. İsim Kültürü ve Din [Name Culture and Religion]. İstanbul: Çizgi Publishing, 2005.

Çelikoğlu, Nalan. Türkiye'de Üniversite Gençliğinde Mahremiyetin Dönüşümü [The transformation of mahrem (privacy) among univesity students in Turkey]. Master thesis. Marmara University, 2007.

Çetin, Adnan. “Bir Kavramın Kısa Tarihi: Mahalle Baskısı [A Brief History of a Concept: 'Peer Pressure'].” Mukaddime, 2:1 (2010), 81-92.

Davie, Grace. Europe: The Exceptional Case. London: Darton, Longman and Todd, 2002.

Dinçer, Özüm. Namus ve Bekâret: Kuşaklar Arasında Değişen Ne? Iki Kuşaktan Kadınların Cinsellik Algıları [Virtue and Virginity: What Is the Difference between Generations?]. Master thesis. Ankara University, 2007. Retrieved from http:// ulusaltezmerkezi.com/namus-ve-bekaret-kusaklar-arasinda-degisen-ne-iki-kusaktan-kadinlarin-cinsellik-algilari/62/

Dressler, Markus. “Religio-Secular Metamorphoses: Re-Making of Turkish Alevism.” Journal of American Academy of Religion, 76:2 (2008), 280-311. DOI: https://doi.org/10.1093/jaarel/lfn033

Doğruel, Fulya \& Leman, Johan. “'Conduct' and 'Counter-conduct' on the Southern Border of Turkey: Multicultural Antakya.” Middle Eastern Studies, 45:4 (2009), 593-610. DOI: 10.1080/00263200903009650

Eke, Nurcan Pınar. Bedene müdahalenin bir yolu olarak moda ve medyada sunulan beden algısı [The Fashion as a Way of the Intervention for Body and the Perception of Body Presented in Media]. Docoral thesis. Selçuk University, 2013.

Erdem, Muharrem. Secrets and Revelations: An Ethnographic Study of the Nusayr community in the Karaduvar District of Mersin. Master thesis. Middle East Technical University, 2010.

Erdemir, Aykan. Incorporating Alevis: The Transformation of Governance and Faith Based Collective Action in Turkey. Doctoral thesis. Harvard University, 2004.

Erdentuğ, Nermin. Türkiye Türk Toplumlarında kültürel antropolojik (etnolojik) incelemeler [Cultural anthropological (ethnological) examinations in Turkish Turkish societies]. Ankara: Ankara University Publishing, 1972.

Erdoğan, İlker. “Erkek Dergilerinde (Men’s Health-FHM-Esquire-GQ Türkiye Örneğinde) İdeal(leştirilen) Erkek(lik) İmajının İçerik Çözümlemesi [A Content Analysis of Ideal(ized) Masculin(ity)'s Image in Men's Magazines (A Sample of Men's Health-FHM-Esquire-GQ Turkey)]." Journal of Akdeniz University Communication Faculty, 10: 20 (2013), 140-164.

Erkan, Rüstem. “Türkiye'de ve Güneydoğu Anadolu Bölgesinde Boşanma [Divorce in Turkey and Southeastern Anatolia Region].” In Tüm Yönleriyle Boşanma [All Aspects Related to Divorce], edited by Sabri Eyigün, Ramazan Günay, Ömer Ergün \& Hatip Yıldız, 11-20. Diyarbakır: Dicle University, 2013.

Ertit, Volkan. Endişeli Muhafazakarlar Çağı [The Age of Anxious Conservatives]. Ankara: Orient Publishing, 2015.

Ertit, Volkan. Secularization of Alevis in Turkey. An Extension of Steve Bruce's Secularization Paradigm and Its Application to Alevi Communities in Turkey. Doctoral thesis. Radboud University, 2017. Retrieved from http://repository.ubn.ru.nl/ bitstream/handle/2066/168473/168473.pdf [last visited 11/04/2018]

Ertit, Volkan. “Secularization: The Decline of the Supernatural.” Religions, 9:4 (2018), 92. DOI: 10.3390/rel9040092

Fırat, Kamil. "Ankara'da Bir Alan Araştırması: Aleviliğin ve Dinsel Kimliğin Alevilerce Algılanması [A Field Survey in Ankara: The Alevi Perception of Alevism and Religious Identity]." Kırkbudak, 1:1 (2005), 50-69.

General Directorate of Population and Citizenship Affairs. "İsim İstatistikleri [Name Statistics].” 2016, October 10. In www.nvi. org.tr. Retrieved from https://www.nvi.gov.tr/hizmetlerimiz/istatistikler/isim-istatistikleri [Last visited 11/04/2018]

General Directorate of Sport. "Diyanet İşleri Başkanlığı ile Spor Genel Müdürülüğü arasındaki Protokol [Cooperation Protocol between the Directorate of Religious Affairs and the Directorate General of Sports]." In http://sgm.gsb.gov.tr/ Retrieved from https://sgm.gsb.gov.tr/Public/Edit/images/SGM/Mevzuat/Protokoller/D\%C4\%BOYANET\%20PROTOKOL.pdf [Last visited 11/04/2018]

Glock, Charles.Y. “On the Study of Religious Commitment.” Religious Education, 57:S4 (1962), 98-110. DOI: $10.1080 / 003440862057 S 407$

Gökarıksel, Banu \& Secor, Anna J. “'Even I Was Tempted”: The Moral Ambivalence and Ethical Practice of VeilingFashion in Turkey." Annals of the Association of American Geographers, 102:4 (2011), 847-862. DOI: 10.1080/00045608.2011.601221

Gökarıksel, Banu \& Secor, Anna J. “Islam on the Catwalk: Marketing Veiling-Fashion in Turkey.” In The Changing World Religion Map, edited by Stanley D. Brunn, 2581-2595. Dordrecht: Springer, 2015.

Gündoğdu, Yusuf Bahri. “Seçmeli Din Dersleri Neden Tercih Edilmiyor? (Ordu Ili Örneği) [Why Elective Religion Courses Are Not Preferred? (The Case of Ordu Province)]." Journal of Divinity Faculty of Hitit University, 16:32 (2017). 557-582.

Gür, Bekir. S. \& Kurt, Türker. "Türkiye'de Ailelerin Eğitim İhtiyaçları [Educational Needs of Families in Turkey].” Family and Society, 7:27 (2011), 33-62. 
Güven, Ahmet. “Gezi’nin Dili: Göstergebilimsel Bir İnceleme [The Language of Taksim Gezi Park Protests: A Semiotic Review].” Human \& Human, 2 (2014), 19-29.

Haber55. "Eşcinseller Samsun'da 3. Onur Yürüyüşü yaptı [The homosexuals performed the 3rd Honor Walk in Samsun]." 2016, June 20. In www.haber55.com. Retrieved from http://www.haber55.com/escinseller-samsunda-3.-onur-yuruyusuduzenledi/ [Last visited 11/04/2018]

Haber Turk. "Alevi Hukuku Yargıdan Döndü [The judiciary ignored the Alawi law].” 2010, July 7. In www.haberturk.com. Retrieved from http://www.haberturk.com/yasam/haber/530031-alevi-hukuku-yargidan-dondu [last visited 11/04/2018]

Haber Turk. "Devlet Onaylı Ateizm Derneği [Association of Atheism Approved by the State].” 2015, February 26. In www. haberturk.com. Retrieved from http://www.haberturk.com/yasam/haber/940892-devlet-onayli-ateizm-dernegi [Last visited 11/04/2018]

Hurriyet Daily News. "Turkish brewer says rise in homebrewed beer is hitting sales." 2018, February 01. In http://www. hurriyetdailynews.com. Retrieved from http://www.hurriyetdailynews.com/turkish-brewer-says-rise-in-homebrewedbeer-is-hitting-sales-126643 [last visited 11/04/2018]

Hürriyet. “'istanbul'da Sıradışı Bir Düğün [An Extraordinary Wedding in Istanbul].” 2014, September 25. In www.hurriyet.com. Retrieved from http://www.hurriyet.com.tr/istanbul-da-siradisi-bir-dugun-duzen-karsisinda-gizlenmedik-27260988 [Last visited 11/04/2018]

Hürriyet. “Murat Boz Meme Küçültme Ameliyatı Oldu [Murat Boz Got Breast Reduction Surgery].” 2016, March 2. In www. hurriyet.com.tr. Retrieved from http://www.hurriyet.com.tr/murat-boz-gogus-kucultme-ameliyati-oldu-40062706 [Last visited 11/04/2018]

Iftar with Nihat Hatipoğlu. “Erkekler Dar Pantolon Giymemelidir [Men should not wear Narrow Pants]." 2017, June 6. In ATV. Retrieved from https://www.youtube.com/watch?v=JMdoGOnfBH0 [Last visited 11/04/2018]

Kalav, Ayşe. “Namus ve Toplumsal Cinsiyet [Purity and Gender].” Mediterranean Journal of Humanities, II/2 (2012), 151-163. Retrieved from http://mjh.akdeniz.edu.tr/_dinamik/201/406.pdf [Last visited 11/04/2018]

Kaos GL. “Malatya'da LGBTi Onur Yürüyüşü [LGBTI Honor Walk in Malatya].” 2014, June 12. In www.kaosgl.org. Retrieved from http://kaosgl.org/sayfa.php?id=16832 [Last visited 11/04/2018]

Karaarslan, Faruk. "Kitap Kritiği: Endişeli Muhafazakarlar Çağı [Book Review: The Age of Anxious Conservatives]. Journal of Human \& Society, 4:9 (2015), 151-155.

Karaaslan, Selda. 1980 Sonrası Türk Toplumunda Din Eksenli Dönüşümlerin Kadın Kıyafetlerinin Değişimine Yansımaları [Reflections of religious-based social changes on woman clothes in Turkish society after 1980]. Master thesis. Marmara University, 2010.

Kazemipur, Abdolmohammad \& Rezaei, Ali. "Religious Life under Theocracy: The Case of Iran.” Journal for the Scientific Study of Religion, 42:3 (2003), 347-361.

Koç, İsmet, Eryurt, Mehmet Ali, Adalı, Tuğba, Seçkiner, Pelin. Türkiye’nin Demografik Dönüşümü, Doğurganlık, Anne-Çocuk Sağlığı ve Beş Yaş Altı Ölümlerdeki Değişimler:1968-2008 [Turkey’s demographic transformation, Fertility, Mother-Child Health and Changes in Mortality for Under Five: 1968-2008]. Ankara: Hacettepe University Institute of Population Studies.

Köse, Ali. Laik ama Kutsal [Laic but Sacred]. İstanbul: Nesil Publishing, 2006.

Lotfi, Alireza, Kabiri, Sabour \& Ghasemlou, Hojjat. “Değerler Değişimi ve Kuşaklararası Çatışma: İran Khoy Kenti Örneği [Conflict and Change Across Generations: The Khoy Case]." Eskişehir Osmangazi University Journal of Social Sciences, 14:2 (2013), 93-113.

Manço, Ural. "Corporéités, ascétismes et sécularisation dans le discours de la confrérie Naqshbandi turque contemporaine [Corporeity, asceticism and secularization in the speech of the contemporary Turkish Naqshbandi brotherhood]." Social Compass, 57: 4 (2010), 479-492.

Milliyet. “Boyner’in Kürtaj Çıkışına Arınç’tan Azar [Boyner was scolded by Arınç on abortion].” 2012, June 15. In www. milliyet.com.tr. Retrieved from http://siyaset.milliyet.com.tr/boyner-in-kurtaj-cikisina-arinc-tan-azar/siyaset/ siyasetdetay/15.06.2012/1554183/default.htm [Last visited 11/04/2018]

Ministry of Family and Social Policies. Türkiye'de Aile Yapısı Araştırması 2011 [Family Structure Research in Turkey 2011]. Ankara, 2011. Retrieved from http://www.cocukhaklariizleme.org/wp-content/uploads/turkiyenin-aile-yapisiarastirmasi-20111.pdf [Last visited 11/04/2018]

Meşe, İlknur. "Tüketim, Din ve Kadın Bağlamında İslami Moda Dergileri [Veiling Fashion Magazines in Context Concepts of Consumption, Religion, and Woman]." Journal of Social Sciences Eskisehir Osmangazi University, 17:1 (2016), 95-110.

National Education Statistics 2015/'16. Retrieved from http://sgb.meb.gov.tr/meb_iys_dosyalar/2016_03/18024009_meb_ istatistikleri_orgun_egitim_2015_2016.pdf [Last visited 11/04/2018]

Norris, Pippa \& Inglehart, Ronald. Sacred and Secular, Religion and Politics Worldwide. New York, NY: Cambridge University Press, 2008.

NTV. “Erdoğan Kürtaj Cinayettir [Erdoğan: Abortion is murder]." 2012, May 25. In www.ntv.com.tr. Retrieved from https://www. ntv.com.tr/turkiye/erdogan-kurtaj-cinayettir,VgwTj]iEyEuq-9Qcqqy6Ag [last visited 11/04/2018]

Onedio. Türkiye'nin ilk “eşcinsel youtube çifti” [Turkey’s first YouTube “gay couple”]. 2017, April 12. In https://onedio.com. Retrieved from https://onedio.com/haber/turkiye-nin-ilk-escinsel-youtube-cifti-merak-edilenleri-anlatmaya-devamediyor-ilk-bulusma-ve-ailelerin-tanismasi-766307 [Last visited 11/04/2018] 
Ozan, Ömer. Din Görevlisinin Toplumsal İmajını Etkileyen Faktörler (Samsun Örneği) [Factors affecting the image of religious officials (Sample of Samsun)]. Master thesis. Ondokuzmayıs University, 2013.

Ozan, S., Aras S., Semin S., Orcin E. "Sexual attitudes and behaviors among medical students in Dokuz Eylul University, Turkey." The European Journal of Contraception and Reproductive Health Care, 10:3 (2005), 171-183. DOI: $10.1080 / 13625180500282205$

Öniş, Ziya \& Yılmaz, Şuhnaz. "Between Europeanization and Euro-Asianism: Foreign Policy Activism in Turkey during the AKP Era.” Turkish Studies, 10:1 (2009), 7-24. DOI: http://dx.doi.org/10.1080/14683840802648562

Özbolat, Abdullah. "Hutbelerde Söylem Değişimi - Diyanet Hutbeleri Örneği [Change in Discourse in the Sermons the Case of Sermons of Presidency of Religious Affairs]." The Journal of International Social Research, 7:29 (2014), 662-679.

Özcan, Yusuf Ziya. "Ülkemizdeki Cami Sayıları Üzerine Sayısal Bir İnceleme [A Quantitative Study of Mosques in Turkey].” Journal of Islamic Research, 4:1 (1990), 5-20.

Öztürk, Akif. “Eril Bedenselleşme: Hegemonik Erkek Bedeninin İnşası [Male Embodiment: The Construction of the Hegemonic Male Body]." Journal of Philosophy and Social Sciences, 12 (2012), 39-53.

Presidency of Religious Affairs. "Cami Sayısı İstatistikleri [Statistics on Mosques].” 2016, December 31. In www.diyanet.gov. tr. Retrieved from http://www.diyanet.gov.tr/tr-TR/Kurumsal/Detay//6/diyanet-isleri-baskanligi-istatistikleri [Last visited 11/04/2018]

Sabah. "Diyanet’ten Kürtaj Açıklaması [Declaration on Abortion by Religious Presidency].” 2012, June 4. In www.sabah.com.tr Retrieved from http://www.sabah.com.tr/gundem/2012/06/04/diyanetten-kurtaj-aciklamasi [last visited 11/04/2018]

Sabah. "Kıvanç Fit bir vücut için altı ay çalıştı [Kıvanç worked for a fit body for six months]." 2014, January 20. In www.sabah. com.tr. Retrieved from http://www.sabah.com.tr/magazin/2014/01/20/kivanc-fit-bir-vucut-icin-alti-ay-calisti [Last visited 11/04/2018]

Sağır, Adem. "Endişeli Muhafazakarlar Çağı'na Bir Prolegomena [A Prolegomena to The Age of Anxious Conservatives]. Journal of the Human and Social Science Researches, 4:3 (2015), 791-809.

Sarmış, Mustafa. "Hollywood Sinemasının Sekülerleşme Stratejisi [Secularization Strategy of Hollywood]. In Full-Text Book of Symposium on Global Politics and Cinema, edited by Hüseyin Türkan, 49-65. İstanbul: UHIM, 2017.

Semerdjian, Elyse. "Zinah". In The Oxford Encyclopedia of the Islamic World, edited by John L. Esposito. Oxford: Oxford University Press, 2009.

Süleymanov, Abulfez. "Çağdaş Türk Toplumlarında Aile ve Evlilik iliş̧kileri [Family and Marrige Relations in Modern Turkish Societies].” Journal of Social Policy Conferences, 58 (2010), 197-216. Retrieved from http://dergipark.gov.tr/download/ article-file/198190 [Last visited 11/04/2018]

Şener, Cemal. Şamanizm / Türklerin İslamiyet’ten Önceki Dini [Shamanism / Pre-Islamic Religion of Turks]. İstanbul: Etik Publishing, 2001.

T24. "Son 11 yılda 8 bin 743 cami ibadete açıldı [ 8 thousand 743 mosques were built in the last 11 years]." 2013, July 15. In www.t24.com.tr. Retrieved from http://t24.com.tr/haber/cami-sayisi-katlanarak-artti,234351 [last visited 11/04/2018]

Taylan, Hasan Hüseyin \& Danış, Yasemin. “Sosyal Değişme ve Türkiye’de Boşanma Olgusu [Divorce in Turkey and Social Change]." Mehir Aile, 3 (2016), 41-57.

Taylor, Charles. “Two Theories of Modernity.” The Hastings Center Report, 25:2 (1995): 24-33.

Toprak, Binnaz, Bozan, İrfan, Morgül, Tan \& Şener, Nedim. Being Different in Turkey, Research Report on Neighbourhood Pressure. Istanbul: Boğaziçi University \& Open Society Foundation, 2009.

Turkish Statistical Institute. İstatistik Göstergeler 1923-2009 [Statistical Indicators 1923-2009].” Ankara: TÜiK Publishing, 2012. Retrieved from http://www.tuik.gov.tr/yillik/Ist_gostergeler.pdf [last visited 11/04/2018]

Turkish Statistical Institute. "Adrese Dayalı Nüfus Kayıt Sistemi Sonuçları 2016 [Results of Address Based Population Registration System].” 2017 January 31. In www.tuik.gov.tr. Retrieved from http://www.tuik.gov.tr/PreHaberBultenleri. do?id=24638 [last visited 11/04/2018]

Turkish Statistical Institute. "Evlenme ve Boşanma İstatistikleri [Marriage and Divorce Statistics].” 2017, March 02. In www. tuik.gov.tr. Retrieved from http://www.tuik.gov.tr/PreHaberBultenleri.do?id=24642 [Last visited 11/04/2018]

The Economist. "Islâm and Homosexuality, Straight but Narrow.” 2012, February 4. In www.economist.com. Retrieved from http://www.economist.com/node/21546002 [last visited 11/04/2018]

Tüzer, Verda. “Internet, Siberseks ve Sadakatsizlik [Internet, Cybersex and Infidelity]." Current Approaches in Psychiatry, 3:1 (2011), 100-116. Retrieved from http://www.cappsy.org/archives/vol3/no1/cap_03_05.pdf [Last visited 11/04/2018]

Yavuz, Emrah. “Köy İmamlarının Görev Yaptıkları Yerleşim Biriminin Fiziki ve Sosyokültürel Yapısından Kaynaklanan Problemleri Üzerine Sosyolojik Bir İnceleme-Kayseri Pınarbaşı Örneği [A Sociological Review On The Problems Caused By Physical And Sociocultural Structures Of Settlements That The Imams Of The VillageWork - Case Of Kayseri Pınarbaşı]." Religious Studies, 18:47 (2015), 172-197.

Yıkmış, Meral Salman. Hacı Bektaş Veli’nin Evlatları, “Yol”un Mürşitleri Ulusoy Ailesi [Ulusoy Family, Descendants of Hacı Bektaş Veli]. İstanbul: İletişim Publishing, 2014.

Yıldız, M. Cengiz. "Türkiye'de Töre Baskısına Bağlı İntiharlar ve Töre Cinayetleri [The Custom Murders and Suicides Dependent on Custom Compulsion in Turkey]." Abant İzet Baysal University Journal of Social Sciences, 9:16 (2008), 209-231.

Yıldız, Süleyman Murat \& Tüfekçi, Özlem. "Fitness Merkezi Müşterilerinin Hizmet Kalitesine Yönelik Beklenti ve Algılarının Değerlendirilmesi [Assessment of Expectations and Perceptions of Fitness Center Customers for Service Quality].” 
Balikesir University The Journal of Social Sciences Institute, 13:24 (2010), 1-11. Retrieved from http://sbe.balikesir.edu.tr/ dergi/edergi/c13s24/makale/c13s24mk.pdf [Last visited 11/04/2018]

Yılmaz, Hakan. "Türkiye'de Muhafazakârlık. Aile, Cinsellik ve Din [Conservatism, Family, Sexuality and Religion in Turkey]." 2012, August. In www.aciktoplumvakfi.org.tr. Retrieved from http://www.aciktoplumvakfi.org.tr/pdf/muhafazakarlik/04. pdf [Last visited 11/04/2018]

Yılmaz, Nail. Kentin Alevileri [Urbanized Alevis]. İstanbul: Kitapevi Publishing, 2005.

Yılmaz, Sinan. Türk Ailesinin Dönüşümü ve Din [Transition of Turkish Family and Religion]. Doctoral thesis. Marmara University, 2008.

Yılmaz, Volkan. “Yeni Anayasa Sürecinde LGBTi Hakları Hareketi’nin Eşit Yurttaşlık Mücadelesi: Çoğunlukçu Demokrasiye Karşı Anayasal Demokrasi [Fight for Equal Citizenship by the LGBTI Rights Movement in the New Constitution Process: Constitutional Democracy Against Majority Democracy].” In Farklılıkların Birlikteliği [Coexistence of Differences], edited by Ayhan Kaya, 169-181. İstanbul: Hiperlink, 2014.

Zeidan, David. “The Alevi of Anatolia." Middle East Review of International Affairs, 3:4 (1999), 74-89. 